\title{
COMPARING CONTINENTAL CARBONATES WITH OTHER MATERIALS IN DATING A PALEOLAKE
}

\section{J. F. GARCIA, J. S. MESTRES and GEMMA RAURET}

Radiocarbon Laboratory, University of Barcelona - Institut d'Estudis Catalans, C/ Diagonal 647 Barcelona 08028, Spain

\begin{abstract}
We have studied the application of carbonates and organic matter to the radiocarbon dating of a paleolake. The results show a systematic apparent age shift of these materials with respect to contemporary wood. The apparent age of carbonates is evidently due to the hard-water effect, whereas the apparent age of organic matter, systematically younger than carbonates, is attributed to aquatic plants, which metabolize dissolved $\mathrm{CO}_{2}$. Terrestrial plants that deposit organic matter also cause apparent age discrepancies between carbonates and organic matter.
\end{abstract}

\section{INTRODUCTION}

In radiocarbon dating, few comparative studies have been made using different kinds of material (Evin 1980). Among these materials, shells and inorganic sedimentary carbonates are the most problematic (Mook 1980; Evin 1980; Chen \& Polach 1986). The main difficulty lies in determining initial ${ }^{14} \mathrm{C}$ activity (Krajcar-Bronić et al. 1986; Srdoč et al. 1986) and in ascertaining whether these systems have been closed with regard to carbon exchange (Buddemeier et al. 1972; Grant-Taylor 1972). The initial ${ }^{14} \mathrm{C}$ activity of carbonate sediments depends on several factors, among which the activity of dissolved inorganic carbon (DIC) is most important (Buchardt \& Fritz 1980). Initial activity of DIC in continental waters is determined by:

- drainage basin inorganic carbon carried by surface water

- biological productivity

- stream and river discharge and the origin of these waters

- exchange with the atmosphere

- dissolved carbonate rocks

Attempts have been made to determine the initial activity of DIC for different geological environments and climates (Srdoč et al. 1986; Srdoč, Horvatinčić \& Obelić 1983). Some authors (Pazdur, Pazdur \& Szulc 1988; Andrée et al. 1986; Pazdur \& Pazdur 1986; Pazdur 1988; Chen \& Polach 1986) compare carbonate activity with that of contemporary organic matter to determine apparent age $\left(\mathrm{T}_{\mathrm{ap}}\right)$, defined as the difference $\left(\mathrm{T}_{\text {carbonate }}-\mathrm{T}_{\text {organic matter }}\right)$. This apparent age reflects the fact that part of the dissolved carbon in groundwater comes from carbonates with low or zero ${ }^{14} \mathrm{C}$ content (the hard water effect). Aquatic plants, which use dissolved $\mathrm{CO}_{2}$ in photosynthesis, also yield apparent ages modified by this effect (Willkomn \& Erlenkensen 1972; Srdoč, Obelić \& Horvatinčić 1980).

In this study, we investigate a paleolake from northeastern Spain, dating different types of contemporaneous materials and evaluating the hard water effect in dated samples.

\section{BUBAL PALEOLAKE}

Bubal paleolake $\left(0^{\circ} 20^{\prime} \mathrm{W}, 42^{\circ} 37^{\prime} \mathrm{N}\right.$, elevation $\left.1115 \mathrm{~m}\right)$ is located in the southern Pyrenees in the Gallego River valley between Biescas and Sabiñanigo, Huesca, Spain (García 1991). The paleolake is a doline developed over Devonian limestones during the last glaciation, when glaciallytransported sediment sealed the bottom of the depression. Upon glacial retreat, a small, stagnant lagoon about $25 \times 15$ m remained (Menéndez \& Martí 1973; Martí 1977; Montserrat 1991). Carbonates, organic matter and shells infilled the lake at different levels; wood was found in one level. 


\section{SAMPLING \& LABORATORY PROCEDURES}

A well $4.5 \mathrm{~m}$ deep and $1.5 \mathrm{~m}$ in diameter was excavated for sampling. We collected carbonate and organic samples from each level, and wood from $264 \mathrm{~cm}$ depth. Two samples for radiocarbon dating were collected by drilling in the interval $4.5-6 \mathrm{~m}$. To preclude sampling uncertainty, we established wide-level sampling of $3 \mathrm{~cm}$ at each level; this was done because the expected sedimentation rate was approximately $0.5 \mathrm{~mm} \mathrm{yr}^{-1}$, according to recent pollen analysis (Montserrat (ms.) 1991). Figure 1 shows the stratigraphy of Bubal paleolake.

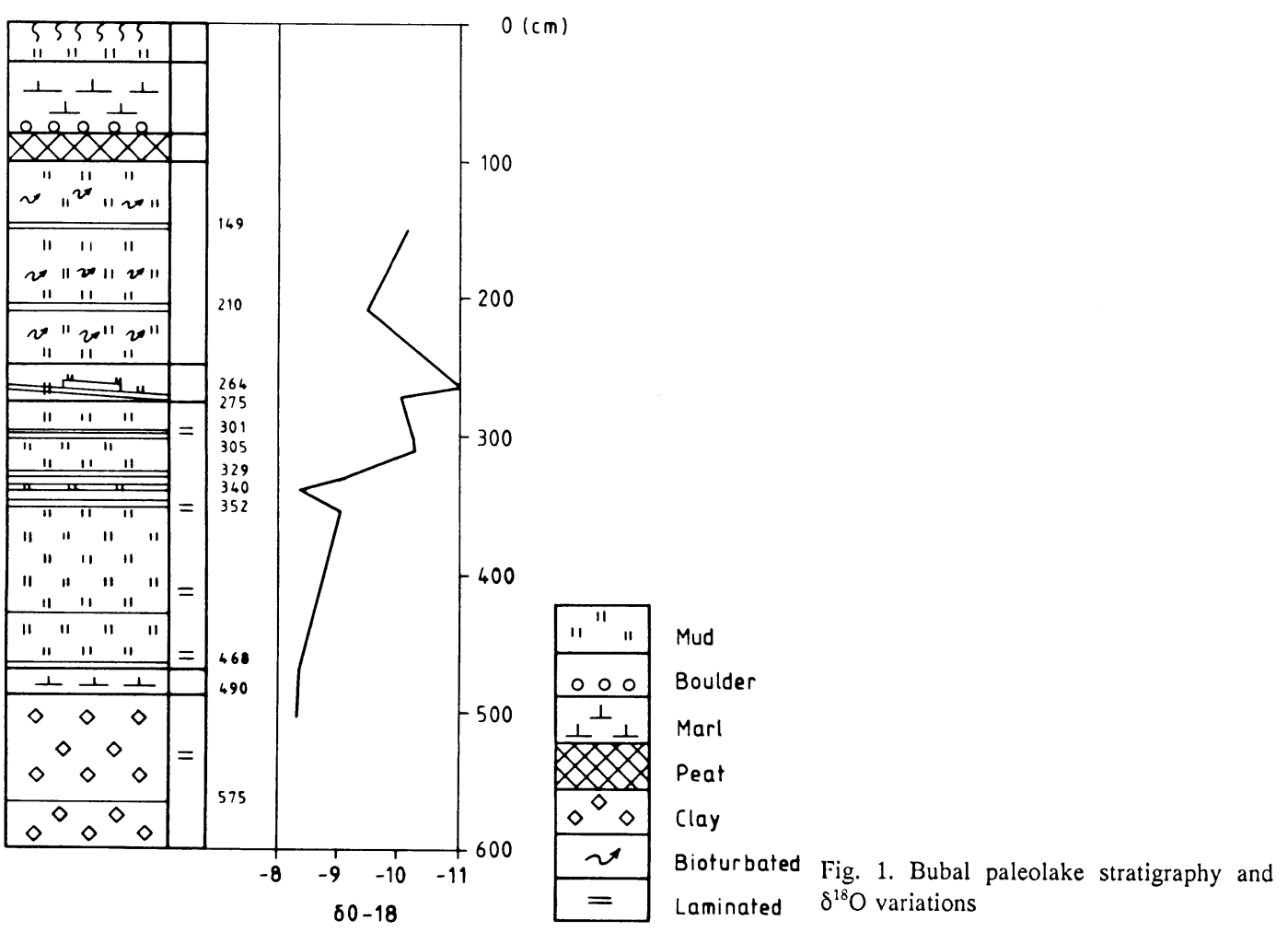

Before analysis, all samples were dried and ground to $<1 \mathrm{~cm}$. We homogenized, quartered and ground each sample to $<1 \mathrm{~mm}$ for determination of organic matter content, carbonate content, $\mathrm{X}$-ray diffraction, stable isotope analysis and ${ }^{14} \mathrm{C}$ dating. Details of each analysis are listed below.

Organic Matter Content: We calcined, at $450^{\circ} \mathrm{C}, \mathrm{ca} .0 .1 \mathrm{~g}$ of sample (previously dried at $110^{\circ} \mathrm{C}$ ) until a constant weight was reached. Relative organic matter content was calculated by mass difference.

Carbonate Content: We suspended in boiling water $c a .0 .1 \mathrm{~g}$ ground sample. We then performed acid-base volumetry using $1 \mathrm{~N} \mathrm{HCl}$ titrimetric solution with slight stirring and a potentiometric indicator (combined glass $\mathrm{pH}$ electrode). The carbonate content was calculated by acid titration to $\mathrm{pH} 3-4$.

$\mathrm{X}$-Ray Diffraction: We performed this analysis on all dated samples using the single-crystal technique. 
Stable Isotopes: We performed $\delta^{13} \mathrm{C}$ and $\delta^{18} \mathrm{O}$ analyses following Gonfiantini (1981) using a V.G. Isogas F.M. SIRA-10 mass spectrometer.

${ }^{14} \mathrm{C}$ dating: $0.05 \%$ of shells was separated from sediments in one level, $264 \mathrm{~cm}$. The small proportion found here led us to date both inorganic carbonate and shell fractions together in each level studied. Using the method described in Mestres, García \& Rauret (1991), we dated organic matter (MO) and carbonates (C) from 5 levels: 149, 264, 305, 329 and $340 \mathrm{~cm}$, and wood (W) from level $264 \mathrm{~cm}$. This sample, $264-\mathrm{W}$, is from a pine trunk $20 \mathrm{~cm}$ in diameter and $50 \mathrm{~cm}$ in length; the outermost 20 rings were dated. At the two deepest levels sampled, we could date only sedimentary carbonates because of the small amount available.

\section{RESULTS AND DISCUSSION}

Table 1 shows our results. Along the stratigraphic sequence, ages of organic materials and carbonates increase with depth. At Level $264 \mathrm{~cm}$, the dates for carbonate sample 264-C (9630 $100 \mathrm{BP})$ and organic matter 264-MO $(9460 \pm 110 \mathrm{BP})$ are similar, but do not agree with the date for the most reliable material, wood sample $264-\mathrm{W}(8830 \pm 100 \mathrm{BP})$.

$\mathrm{X}$-ray diffraction analysis shows that calcite is the main mineral component in all sediment samples. It also reveals that the contribution of dolomite is lower than $2 \%$ at any level. Assuming that dolomite monitors the detrital contribution, then this small proportion is unable to produce stratigraphic inversion of dates. Moreover, the high native carbonate content of the sediments minimizes the relative contribution of external carbonate contamination (Siegenthaler \& Eicher 1986).

TABLE 1. Results from Bubal Paleolake

\begin{tabular}{|c|c|c|c|c|c|c|c|c|c|c|}
\hline $\begin{array}{c}\text { Sample } \\
\text { no. }\end{array}$ & $\begin{array}{c}\text { UBAR } \\
\text { no. }\end{array}$ & $\begin{array}{l}\text { Depth } \\
(\mathrm{cm})\end{array}$ & $\begin{array}{c}{ }^{14} \mathrm{C} \text { age } \\
\text { (BP) }\end{array}$ & $\begin{array}{c}\mathrm{S} \\
\text { age* }^{*}\end{array}$ & $\begin{array}{c}\text { Act. } \\
\left(\mathrm{dpm} \mathrm{g}^{-1} \mathrm{C}\right)\end{array}$ & $\begin{array}{c}\mathrm{S} \\
\text { act. }^{* *}\end{array}$ & $\delta^{13} \mathrm{C}$ & $\delta^{18} \mathrm{O}$ & $\begin{array}{l}\mathrm{MO}^{\dagger} \\
(\%)\end{array}$ & $\begin{array}{l}C^{\ddagger} \\
(\%)\end{array}$ \\
\hline 149-MO & 143 & 149 & 8580 & 110 & 4.061 & 0.052 & -33.88 & & & \\
\hline $149-\mathrm{C}$ & 144 & 149 & 8870 & 100 & 3.918 & 0.049 & -4.78 & -10.17 & 7.3 & 86.8 \\
\hline $210-C$ & & 210 & & & & & -4.89 & -9.51 & 6.3 & 91.6 \\
\hline $264-W$ & 145 & 264 & 8830 & 100 & 3.937 & 0.048 & -26.53 & & & \\
\hline 264-MO & 146 & 264 & 9460 & 110 & 3.641 & 0.049 & -32.69 & & & \\
\hline $264-C$ & 147 & 264 & 9630 & 100 & 3.566 & 0.045 & -4.53 & -11.05 & 16.2 & 78.3 \\
\hline $275-C$ & & 275 & & & & & -4.76 & -10.09 & 17.1 & 78.9 \\
\hline $301-C$ & & 301 & & & & & -4.89 & -10.24 & 8.0 & 87.9 \\
\hline 305-MO & 148 & 305 & 9940 & 120 & 3.430 & 0.050 & -35.34 & & & \\
\hline $305-C$ & 149 & 305 & 10,630 & 120 & 3.147 & 0.044 & -4.63 & -10.26 & 13.5 & 80.8 \\
\hline 329-MO & 150 & 329 & 10,780 & 120 & 3.087 & 0.044 & -28.70 & & & \\
\hline $329 . \mathrm{C}$ & 151 & 329 & 11,390 & 130 & 2.864 & 0.044 & -3.31 & -9.11 & 12.9 & 77.5 \\
\hline $340-C$ & & 340 & & & & & -0.61 & -8.38 & 7.2 & 88.3 \\
\hline $352-C$ & & 352 & & & & & -0.49 & -9.04 & 5.7 & 86.4 \\
\hline $468-C$ & 223 & 468 & 15,480 & 180 & 1.705 & 0.037 & 0.72 & -8.36 & 11.3 & 74.7 \\
\hline $490-C$ & 222 & 490 & 16,030 & 130 & 1.593 & 0.025 & 1.75 & -8.31 & 3.3 & 64.2 \\
\hline 575-MO & $\begin{array}{l}\text { Gif- } \\
8237^{s}\end{array}$ & 575 & 20,800 & 400 & & & & & & \\
\hline
\end{tabular}

*Standard deviation of ${ }^{14} \mathrm{C}$ age

**Standard deviation of activity

${ }^{\dagger}$ Organic matter content in sample

${ }^{\ddagger}$ Carbonate content in sample

${ }^{8}$ Montserrat (1991) 
Using the results from Level $264 \mathrm{~cm}$, we calculated the initial activity $\mathrm{A}_{0}$ and the apparent age $\left(\mathrm{T}_{\mathrm{ap}}\right)$ for carbonates and organic matter, assuming that they were coeval with the external rings of the pine trunk. The values are:

$$
\begin{array}{ll}
\mathrm{A}_{0}(\mathrm{C})=90.6 \% \mathrm{~A} & \mathrm{~T}_{\text {ap }}(\mathrm{C})=800 \mathrm{yr} \\
\mathrm{A}_{0}(\mathrm{MO})=92.5 \% \mathrm{~A} & \mathrm{~T}_{\text {ap }}(\mathrm{MO})=630 \mathrm{yr}
\end{array}
$$

The hard-water effect, which reduces the initial carbonate activity (Srdoč, Obelić \& Horvatinčić 1980; Andrée et al. 1986), appears to account for the finding that organic matter and carbonates are older than the wood.

Carbonates have fairly high $\mathrm{A}_{0}$ values and quite low (young) apparent ages. These results agree with those from Sieradowice, Poland (Pazdur, Pazdur \& Szulc 1988; Pazdur 1988), a site with similar hydrodynamic conditions, stagnant water and semilimnic deposition of calcareous muds. Here, $A_{0}=89 \%$ and $T_{a p}=910 \pm 120 \mathrm{yr}$. Comparable values were also found for the same Preboreal period by Andrée et al. (1986), who dated terrestrial plant macrofossils, aquatic plant remains and carbonates from Lake Lobsinger; they measured an apparent age of $800 \mathrm{yr}$.

These high initial $\mathrm{A}_{0}$ values may be explained by considerable exchange between dissolved and atmospheric $\mathrm{CO}_{2}$, which could be related to water residence time in the paleolake (Srdoč, Obelić \& Horvatinčić 1980).

In all levels dated, the similarity between the ages of carbonates and organic matter may be explained by the fact that the organic matter comes mainly from aquatic plants (Menéndez \& Martí 1973) which used dissolved $\mathrm{CO}_{2}$ for photosynthesis (Willkomn \& Erlenkensen 1972; Srdoč et al. 1986). Nevertheless, in all comparisons, carbonates are systematically older than organic matter. This could be explained by the presence of a minor terrestrial plant component in organic matter derived mostly from aquatic plants. Assuming that terrestrial plant activity, $A_{1}$, is that of the wood sample 264-C, and that aquatic plant activity, $A_{a q}$, is that of carbonate samples at $264 \mathrm{~cm}$ depth, we calculate the proportion of plants from the two sources

$$
A=a \cdot A_{a q}+(1-a) A_{t}
$$

and obtain $79.8 \%$ aquatic plants, and $20.2 \%$ terrestrial plants.

For the other levels dated, we calculated the difference between carbonate age, $T_{c}$, and organic matter age, $T_{m o}$, which from its similarity with $T_{a p}$, may be called $T_{a p}$,

$$
\mathrm{T}_{\mathrm{ap}}=\mathrm{T}_{\mathrm{c}}-\mathrm{T}_{\mathrm{mo}}
$$

Table 2 shows the values of $T_{a p}$, for each level dated. A discontinuity is seen between levels 264 and $305 \mathrm{~cm}$; the $T_{a p}$, values below $305 \mathrm{~cm}$ are around $600-700 \mathrm{yr} \mathrm{BP}$, while the values are 200-300 yr BP toward the top of the section. This discontinuity also appears in pollen data for the drier and colder Younger Dryas period, between 354 and $305 \mathrm{~cm}$ depth in the Bubal section. Montserrat (1991) found, by principal component analysis, 8 different pollen zones corresponding to distinct pollen assemblages. He concluded that the Younger Dryas appeared in zone BUB-5 (394-354 cm) with the appearance of steppe Artemisia, and disappeared in BUB-3 $(321-305 \mathrm{~cm})$ with the presence of Quercus.

The relation between environmental changes and $\delta^{18} \mathrm{O}$ values of lake carbonates is complex (Siegenthaler \& Eicher 1986). $\delta^{18} \mathrm{O}$ values (Fig. 1) show a change between 264 and $340 \mathrm{~cm}$ depth, 
TABLE 2. Difference between Carbonate Age $\left(T_{C}\right)$ and Organic Matter Age $\left(\mathrm{T}_{\mathrm{mo}}\right)$

\begin{tabular}{cc}
\hline Level & $\mathrm{T}_{\mathrm{ap}{ }^{*}}$ \\
\hline $146-149$ & $290 \pm 150^{* *}$ \\
$261-264$ & $170 \pm 150^{* *}$ \\
$304-305$ & $690 \pm 170^{* *}$ \\
$326-329$ & $610 \pm 170^{* *}$ \\
\hline
\end{tabular}

$$
\begin{aligned}
& * \mathrm{~T}_{\mathrm{ap}}=\mathrm{T}_{\mathrm{c}}-\mathrm{T}_{\mathrm{mo}} \\
& { }^{*} \mathrm{oT}_{\mathrm{ap}}=\left[\left(\sigma_{\mathrm{mo}}\right)^{2}+\left(\sigma_{c}\right)^{2}\right]^{1 / 2}
\end{aligned}
$$

similar to that obtained by Duplessy et al. (1981) through correlation of deep-sea cores from the Bay of Biscay with six continental sites in France and Spain. In this study, the Younger Dryas is dated at $c a .10,400 \mathrm{BP}$; its end is related to the disappearance of Artemisia and the increase of Quercus, as found at Bubal.

Sedimentation rates were calculated from the ${ }^{14} \mathrm{C}$ results (Table 3 ). The sedimentation rate above $264 \mathrm{~cm}$ is higher than below $304 \mathrm{~cm}$, and intermediate between the two layers. This change occurs at the same depth as the change in the $T_{a p}$, values, and corresponds to $\mathrm{X}$-ray results showing only dolomite at $275 \mathrm{~cm}$ depth. These data support the occurrence of a change with the variation of $T_{a p}$.

TABLE 3. Sedimentation Rates

\begin{tabular}{ccc}
\hline $\begin{array}{c}\text { Depth } \\
(\mathrm{cm})\end{array}$ & $\begin{array}{c}\text { Sedimentation rate } \\
\text { organic matter }\left(\mathrm{mm} \mathrm{yr}^{-1}\right)\end{array}$ & $\begin{array}{c}\text { Sedimentation rate } \\
\text { carbonates }\left(\mathrm{mm} \mathrm{yr}^{-1}\right)\end{array}$ \\
\hline $149-264$ & 1.31 & 1.52 \\
$264-305$ & 0.85 & 0.41 \\
$305-329$ & 0.28 & 0.31 \\
$468-490$ & - & 0.40 \\
$329-575$ & 0.25 & - \\
\hline
\end{tabular}

For contemporary samples, the difference between $T_{m o}$ and $T_{c}$ is given by

$$
\mathrm{T}_{\mathrm{ap}},=\mathrm{T}_{\mathrm{c}}-\mathrm{T}_{\mathrm{mo}}=\frac{\mathrm{t}_{1 / 2}}{\ln 2} \ln \left(\mathrm{a}+\frac{(1-\mathrm{a})}{\mathrm{f}_{\mathrm{c}}}\right)
$$

where: $\mathrm{a}=$ fraction of aquatic plants

$f_{c}=$ the factor establishing the relationship between the ${ }^{14} \mathrm{C}$ activity in the atmosphere and the initial ${ }^{14} \mathrm{C}$ activity of carbonates.

$t_{1 / 2}={ }^{14} \mathrm{C}$ half-life.

Some studies suggest that the apparent age of carbonates $\left(\mathrm{T}_{\mathrm{ap}}\right)$ for a given site remains constant, especially in stagnant water (Pazdur \& Pazdur 1986; Pazdur, Pazdur \& Szulc 1988), which means $f_{c}$ is constant. If we assume this, the increase in $T_{a p}$, values should relate to a change in the proportion, a, between the aquatic and terrestrial plant components of the organic matter dated. This hypothesis has been corroborated by pollen analysis which shows a substantial change from terrestrial plant pollen to aquatic plant pollen from $270 \mathrm{~cm}$ depth downward (Montserrat 1991). Thus, from $304 \mathrm{~cm}$ depth, the initial activity of the organic matter should be closer to atmospheric values 
than in the upper levels, and $\mathrm{T}_{\mathrm{ap}}$, would be higher. This explanation seems more reasonable than to expect a sudden change in the component that provides the ${ }^{14} \mathrm{C}$ to the system. Another hypothesis is that organic matter and carbonates were not deposited at the same time, and thus may have different real ages.

\section{CONCLUSIONS}

The results obtained in the Bubal Paleolake study confirm those found at other locations with similar hydrodynamic and lithological conditions. The values of initial carbonate activity and $T_{a p}$ depend on several factors that do not permit generalization. Nevertheless, the results from Bubal should establish a chronology for climatic change in this area; specific studies of the geochemical conditions at similar Pyrenean lakes could yield ${ }^{14} \mathrm{C}$ results where carbonates are the only materials available.

\section{ACKNOWLEDGMENTS}

The authors thank the members of the IPE (Instituto Pirenaico de Ecología), especially Joan Montserrat, and R. Julià (Inst. Jaume Almera CSIC) for their assistance in sampling and discussion of part of this paper; also to J. Merín of the Stable Isotope Laboratory (Analytical Chemistry Dept., Univ. Barcelona) for the $\delta^{18} \mathrm{O}$ analyses.

\section{REFERENCES}

Andrée, M., Oeschger, H., Siegenthaler, U., Riesen, T., Moell, M., Ammann, B. and Tobolski, K. $1986{ }^{14} \mathrm{C}$ dating of plant macrofossils in lake sediment. In Stuiver, M. and Kra, R.S., eds., Proceedings of the 12th International ${ }^{14} \mathrm{C}$ Conference. Radiocarbon 28 (2A): 411-416.

Buchardt, B., and Fritz, P. 1980 Environmental isotopes as environmental and climatological indicators. In Fritz, P. and Fontes, J.-Ch., eds., Handbook of Environmental Isotope Geochemistry. Amsterdam, Oxford, N.Y., Elsevier Scientific: 473-504.

Buddemeier, R. W., Okanoto, H. S., Hurd, D. C. and Hufen, T. H. 1972 Effects of solution and exchange on the radiocarbon dating sediments and natural waters. In Rafter, T. A. and Grant-Taylor, T. L., eds., Proceedings of the 8th International ${ }^{14} \mathrm{C}$ Conference. Wellington, Royal Society of New Zealand C:73-86.

Chen, Y., and Polach, H. 1986 Validity of ${ }^{14} \mathrm{C}$ ages carbonates in sediments. In Stuiver, M. and Kra, R. S., eds., Proceedings of the 12 th International ${ }^{14} \mathrm{C}$ Conference. Radiocarbon 28(2A):464-472.

Duplessy, J. C., Delibrias, G., Turon, J. L., Pujol, C. and Duprat, J. 1981 Deglacial warming of the northeastern atlantic ocean: correlation with the paleoclimatic evolution of the European continent. Palaeogeography, Palaeoclimatology, Palaeoecology 35: 121-144.

Evin, J. 1980 Materials of terrestrial origin used for radiocarbon dating. In Mook, W. G. and Walterbolk, H. T., eds., Proceedings of the International Symposium Archaeology and ${ }^{14}$ C. PACT 8-IV: 235-276.

García, J. F. 1991 (ms.) Estudio y optimización del procedimiento de datación por ${ }^{14} \mathrm{C}$ mediante el

método del centelleo líquido. Ph.D. dissertation. Publicacions Universitat de Barcelona, Barcelona, $\mathrm{p}$ 303. ISBN 84-7875-089-4.

Gonfiantini, R. 1981 Stable isotope hydrology. Deuterium and oxygen-18 in water cycle. Technical Reports Series 210. Vienna, IAEA.

Grant-Taylor, T. L. 1972 Conditions for the use of calcium carbonate as a dating material. In Rafter, T. A. and Grant-Taylor, T. L., eds., Proceedings of the 8th International ${ }^{14} \mathrm{C}$ Conference. Wellington, Royal Society of New Zealand G: 56-59.

Krajcar-Bronić, I., Horvatinčić, N., Srdoč, D. and Obelić, B. 1986 On the initial C-14 activity of karst aquifers with short mean residence time. In Stuiver, M. and Kra, R. S., eds., Proceedings of the 12th International ${ }^{14} \mathrm{C}$ Conference. Radiocarbon $28(2 \mathrm{~A})$ : 436-440.

Martí, C. E. 1977 Altos valles de los ríos Aragón y Gallego. Trabajos sobre Neogeno-Cuaternario 6: 157-165.

Menéndez, J. and Martí C.E. 1973 Los sedimentos lacustres de Búbal (Alto Aragón). Pirineos 107: 47-54.

Mestres, J. S., García, J. F. and Rauret, G. 1991 The radiocarbon laboratory at the University of Barcelona. Radiocarbon 33(1): 23-34.

Montserrat, J. 1991 (ms.) Evolución Glaciar y Postglaciar del clima y la vegetación en la vertiente sur del Pirineo: Estudio palinológico. Ph.D. dissertation. Universidad de Barcelona:115 p.

Mook, W. G. 1980 Carbon-14 hydrogeological studies. In Fritz, P. and Fontes, J. Ch., eds., Handbook of Environmental Isotope Geochemistry. Amsterdam, 
Oxford, N.Y., Elsevier Scientific: 49-74.

Muller, A. B. and Mayo, A. L. $1986{ }^{13} \mathrm{C}$ variation in limestone on an aquifer-wide scale an its effects on groundwater ${ }^{14} \mathrm{C}$ dating models. Radiocarbon $28(3)$ : 1041-1054

Pazdur, A., 1988 The relation between carbon isotope composition and apparent age of freshwater tufaceous sediment. Radiocarbon 30(1): 7-18.

Pazdur, A. and Pazdur, M. $1986{ }^{14} \mathrm{C}$ dating of calcareous tufas from different environments. In Stuiver, M. and $\mathrm{Kra}$, R. S., eds., Proceedings of the 12th International ${ }^{14} \mathrm{C}$ Conference. Radiocarbon $28(2 \mathrm{~A}): 534-538$.

Pazdur, A., Pazdur, M. and Szulc, J. 1988 Radiocarbon dating of Holocene calcareous tufa in southern Poland. Radiocarbon 30(2): 133-151.

Siegenthaler, U. and Eicher, U. 1986 Stable oxygen and carbon isotope analyses. In Berglund, B. E., ed., Handbook of Holocene Palaeoecology and Palaeohydrology. New York, John Wiley \& Sons: 407-422.

Srdoč, D., Obelić, B. and Horvatinčić, N. 1980 Radiocarbon dating of calcareous tufa: How reliable data can we expect?. In Stuiver, M. and Kra, R. S., eds., Proceedings of the 10 th International ${ }^{14} \mathrm{C}$ Conference. Radiocarbon 22(3): 858-862.

Srdoc, D., Horvatinčić N. and Obelić, B. 1983 Radiocarbon dating of tufa in paleoclimatic studies. In Stuiver, M. and Kra, R. S., eds., Proceedings of the 11 th International ${ }^{14} \mathrm{C}$ Conference. Radiocarbon 25(2): 421-427.

Srdoč, D., Krajcar-Bronić, I., Horvatinčić, N. and Obelić, B. 1986 Increase of ${ }^{14} \mathrm{C}$ activity of dissolved inorganic carbon along a river course. In Stuiver, M. and $\mathrm{Kra}$, R. S., eds., Proceedings of the 12th International ${ }^{14} \mathrm{C}$ Conference. Radiocarbon $28(2 \mathrm{~A}): 515-$ 521.

Willkomn, H. and Erlenkensen, H. $1972{ }^{14} \mathrm{C}$ measurements of water, plants and sediments of lakes. In Rafter, T. A. and Grant-Taylor, T. L., eds., Proceedings of the 8th International ${ }^{14} \mathrm{C}$ Conference. Wellington, Royal Society of New Zealand D: 1-12. 